\title{
THE PRESENCE OF NEWER EU MEMBER STATES IN THE EUROPEAN EXTERNAL ACTION SERVICE'S STAFF: THE CASE OF SLOVAKIA
}

\author{
Erik PAJTINKA \\ Matej Bel University, Faculty of Political Science and International Relations \\ Banska Bystrica/ Slovakia
}

\begin{abstract}
The article evaluates the representation of Slovakia within the selected categories of the European External Action Service (EEAS) staff in 2012-2019 and drafts possible factors influencing the representation of Slovakia in this EU institution. The evaluation is based on the analysis of statistical data available in EEAS official documents, as well as empirical data obtained from interviews with EU diplomats working for the EEAS. It is concluded, Slovakia's representation within the EEAS's staff between 2012 and 2019 is was inadequate. This may be due to the Slovak Ministry of Foreign Affairs' overall attitude toward the work of its diplomats in the EEAS, its career advancement system, and its institutional culture, and to the conditions under which applicants are selected to posts within the EEAS.
\end{abstract}

Keywords: European External Action Service; geographic balance in the European External Action Service; European Union diplomacy; Slovakia. 


\section{INTRODUCTION}

The European External Action Service (EEAS), which was formally established by the Treaty of Lisbon in December 2009 and started its full operations in January 2011, is the diplomatic body of the European Union (EU). In practice, the EEAS can be considered the first 'real' diplomatic (or foreign) service of the EU. It is because - unlike its predecessor, the External Service of the European Commission, which was an integral part of the organizational structure of the European Commission (EC) - the EEAS is an autonomous EU body, separated from the EC and the Council of the EU (the Council). As the de facto diplomatic service of the EU, the EEAS is headed by the 'EU Foreign Minister', officially titled the High Representative of the EU for Foreign Affairs and Security Policy (High Representative). The internal organization, bureaucratic hierarchy and functioning of the EEAS is regulated by the Council Decision, adopted in July 2010. The Decision stipulates, inter alia, that the EEAS staff at AD level (that is, in fact, diplomatic staff) should consist of at least 60 percent of EU permanent officials and at least one third of EU member states diplomats, temporarily seconded to the EEAS by national diplomatic services. However, the Decision does not set any 'national quotas' for individual EU member states in the EEAS staff, and only vaguely states that 'the staff of the EEAS should comprise a meaningful presence of nationals from all the member states' (Council of the European Union 2010).

Since the staff of the EEAS should carry out their duties and conduct themselves solely with the interest of the Union in mind' (Council of the European Union 2010) according to the Council Decision of 2010, from a purely legal point of view, the question of presence of individual EU member states within the EEAS staff seems to be irrelevant. In practice, however, there are many good reasons why is the question of 'geographic balance' within the EEAS staff relevant and important for both, the EU member states and the EEAS itself. For instance, the presence of diplomats from all EU member states in the EEAS staff enables the EEAS to 'draw from a wide variety of diplomatic cultures and experiences' (Rettman 2010) and improve its quality. It also ensures that EU member states 'feel they have ownership of the service' and that their respective 
populations believe that the EU's foreign policy institutions work in their interest (AFP 2010); this, in turn, strengthens EU member states' positive perceptions of the EEAS and motivates them to engage in EU diplomacy. Furthermore, working for the EEAS provides unique professional experience which staff members might later apply in their respective national diplomatic services. In short, participation and representation in the EEAS is an opportunity for EU member states to improve their own diplomats' skills, national diplomatic services, and EU diplomacy more generally. Although legally EEAS staff 'shall neither seek nor take instruction from any government' (Council of the European Union 2010), states usually exercise some degree of informal influence over their nationals in the EEAS in practice (Henókl 2014). Therefore, EU member states want to be represented in the EEAS's staff to safeguard their channels of influence and keep their eyes and ears in the service.

Thus, it is not surprising that the issue of EU member states' representation on the EEAS staff was a major topic of discussion during the 2009-10 debates about the service's future. The issue was of special concern for newer EU member states, whose representatives emphasised 'the need for geographical balance' (Ministry of Foreign Affairs, Republic of Slovenia 2010), claimed that the 'proportional representation of member states' should be a 'key principle' of the EEAS (Ministry of Foreign Affairs of the Czech Republic 2010), and stressed their desire to see 'all EU member states represented in the EEAS and geographical balance observed' (Ministry of Foreign Affairs of the Republic of Latvia 2010). In addition, some of these countries' members of European parliament proposed hiring quotas to ensure the adequate representation of all EU member states in the service, which was, however, eventually rejected.

Almost a decade later, this study examines evolution of individual EU member states' representation within the EEAS staff to determine how successfully these decisions were implemented. It uses Slovakia's representation in the EEAS staff between 2012 and 2019 as a case study. It evaluates general development trends, analyses and compares statistical data from the EU, considers data collected from interviews with EEAS staff members, and discusses possible factors influencing Slovakian representation in the EEAS's staff. 
This study proceeds as follows. Section two conducts a short literature review. Section three explains this study's methodology and research methods, paying special attention to defining and evaluating adequate representation in the EEAS staff. Section four defines EEAS staff's roles and positions in the EEAS's bureaucratic hierarchy. Sections five and six analyse Slovakia's representation in the EEAS's staff. Section seven discusses possible factors influencing Slovak representation in the EEAS's staff, and section eight concludes and reflects upon this paper.

\section{LITERATURE REVIEW}

The literature on the EEAS's organisation and functioning pays relatively little attention to the representation of individual EU member states within the EEAS staff. However, several researchers addressed this issue in their academic works in recent years. For example, Duke and Lange (2013) analysed the presence of individual EU member states within the EEAS staff over first two years the EEAS's existence, concluding that 'many of the newer EU member states (post 2004 and 2007) were under-represented as a percentage of overall AD level (diplomatic) staff", noting that 'it is not clear whether this was the result of the overall availability of national diplomats for EEAS positions, or whether it is an issue of qualifications and experience for highly competitive appointments'. Formuszewicz and Kumoch (2010) examined the first appointments of EU delegation heads in terms of nationality structure, concluding that 'clear discrepancy is visible in how individual Member States' nationals are represented within the service', pointing out that 'only two Heads of Delegation - out of 115 worldwide - were citizens of the new Member States'. Formuszewicz and Liszczyk (2013) explored the EEAS's staffing policy and its effects on representation, concluding that disparity between the 'old' and 'new' EU member states in the EEAS staff structure, inherited from DG RELEX, has been 'reduced, but not eliminated', either at the headquarters or in the EU delegations, adding that it is advisable in this connection to focus more on the recruitment practices which should be more transparent and accountable for EU 
member states. Novotná (2014) analysed how effective EU member states were at getting their nationals within the EEAS staff in 2010-14, concluding that 'new Member States were not particularly successful at filling posts in the early years', which is especially true for senior management posts. Most recently, Dostál and Fuchsová (2019) analysed the representation of Czech nationals within the EEAS staff, focusing not only on the numbers and share of Czechs in the EEAS diplomatic staff, but also on the geographic distribution of posts occupied by Czech nationals within the network of EU delegations around the world, concluding that although, overall, the Czechs are overrepresented in the EEAS diplomatic staff, the 'Czech' posts in EU delegations are located in countries that are not a priority from the perspective of Czech foreign policy, and thus are relatively less 'valuable'. Beside academic works, there are also several documents produced by EU institutions which review the issue of representation vis-à-vis the EEAS staff. The most important of these is the EEAS's annual human resources report, which provides various statistics on EEAS staff and breaks down the staff by nationality.

The abovementioned academic works and documents generally focus on a relatively short period or particular questions of the EU member state's representation in the EEAS staff and do not provide a comprehensive evaluation of an EU member state representation in the EEAS staff. In order to address this gap in the academic literature, this study brings a comprehensive look at the EU member state representation in the EEAS staff in 2012-2019 on the example of Slovakia. Moreover, it includes also the section trying to explain possible causes of this development.

\section{METHODOLOGY: EVALUATING MEMBER STATES' REPRESENTATION IN THE EEAS}

It is practically impossible for all EU member states to be equally represented within the EEAS, in part because small EU member states are unable to allocate sufficient staff for the needs of the EEAS. Thus, we should evaluate 
representation within the EEAS staff not by comparing the numbers of EEAS staff from each EU member state, but should instead take into account member states' capacity to supply the EEAS with staff. For this reason, the EEAS itself judges EU member states' representation in the EEAS by comparing the proportion of the EEAS's staff belonging to a given state to that state's proportion of the EU population as a whole. The basic principle of this methodology will also be used in this work. First, this paper establishes a hypothetical national quota (HNQ) for EEAS staff on the basis of a state's percentage of the EU population at large. We call our measure a hypothetical quota because the EU itself does not employ a quote when filling positions within the EEAS. A state's HNQ value therefore represents the optimal number of posts its representatives should receive within the EEAS staff, by category (see section 4 for a full breakdown of the categories of EEAS staff):

Total Number of EEAS Staff (in a given category)

$\mathrm{HNQ}=\%$ of total EU population of an EU member state $\times$ 100

The resulting HNQ value will be then deducted from the actual number of posts an EU member state has been given within a particular category of the EEAS staff, according to the formula:

Number of posts given to an EU member state in a given category within the EEAS staff $-\mathrm{HNQ}=\mathrm{X}$.

A state's representation within a given category of the EEAS staff will be then evaluated depending on the value of $\mathrm{X}$, according to the following rules:

a) If the value of $X$ is between -1 and 1 , a state is considered to be adequately represented;

b) If the value of $\mathrm{X}$ is higher than 1 , a state is considered to be overrepresented; 
c) If the value of $\mathrm{X}$ is lower than -1 , a state is considered to be underrepresented.

The degree of a state's representation is expressed in the number of its extra or missing posts in a given category of the EEAS staff. The number of extra or missing posts will be calculated as the value of $X$ rounded down to the nearest whole number.

This paper also assesses states' representation within the EEAS staff on the whole as an auxiliary parameter, and compares this with their percentage of the EU population as a whole - especially when assessing the development of the EEAS over time.

\section{CATEGORIES OF EEAS STAFF AND THEIR POSITION WITHIN THE EEAS'S BUREAUCRATIC HIERARCHY}

EEAS staff are either statutory staff or non-statutory staff, and each of these are divided into several categories. The former includes administrators (AD staff), assistants (AST staff), contract agents, and local agents; the latter includes seconded national experts (SNEs), junior professionals in delegations, stagiaires, and external staff. Each of these categories of staff within the EEAS have specific roles and functions which determine their position within the EEAS bureaucratic hierarchy - these are covered in turn, below.

AD staff perform 'managerial, conceptual and analytical duties' (Regulation No. 31 (EEC) 2014). In practice, their duties are similar to those of diplomats in national diplomatic services. AD staff are, by and large, the staff category most actively involved in the core business of the EEAS - i.e., the implementation of EU diplomacy - and occupy the de facto highest position within the EASS's bureaucratic hierarchy. AD staff themselves can be further sub-divided into officers and temporary agents (TAs). Whereas officers are permanent employees of the EEAS, TAs are diplomats from EU member states' national diplomatic services who are temporarily ${ }^{1}$ attached to the EEAS. 
AST staff and AST/SC staff are tasked with 'executive and technical duties' and 'clerical and secretarial duties' (Regulation No. 31 (EEC) 2014). AST staff perform roles are similar to those of administrative and technical staff in national diplomatic services - they assist AD staff in the implementation of their diplomatic tasks. Thus, they are lower in the EEAS's bureaucratic hierarchy than AD staff.

Contract agents 'carry out manual or administrative support service tasks' and perform the duties of temporarily absent EEAS staff (European External Action Service 2017). By contrast, local agents are tasked with 'manual or service duties' (European External Action Service 2017). Their duties are similar to those performed by service and/or locally engaged staff in national diplomatic services. Unlike the three other categories of EEAS staff listed above, local agents are only found at EU delegations, and not at the EEAS headquarters in Brussels. In addition, they are usually citizens of the respective receiving state, and not the citizens of the EU and its member states.

Regarding non-statutory staff, SNEs perform functions similar to those of AD staff; they are involved in the implementation of EU diplomacy. Unlike AD staff, however, the employment costs of SNEs are covered, fully or partially, by their sending national diplomatic services of EU member states. As a result, the number of SNEs within the overall EEAS staff and the representation of states within this category of EEAS staff depend mostly on various national diplomatic services' willingness to send their diplomats to these posts and cover their costs. Regarding the rest of the EEAS's non-statutory staff, stagiaries and junior professionals in delegations belong to trainee staff, and external staff are contracted by private companies or job agencies to deliver specialised services or carry out short-term duties for the EEAS.

This study will focus primarily on EEAS statutory staff - AD staff, AST staff, contract agents, and SNEs - because these are the most important categories of EEAS staff in terms of the functions performed, having the most significant influence on the performance of EEAS core business, that is EU diplomacy. Other categories of EEAS staff are less relevant to this paper because of their very limited possibilities of influencing the EEAS core activities and in some cases also no representation of EU member states citizens in these categories of 
EEAS staff (for example, local agents are usually recruited from among the citizens of third countries).

\section{SLOVAKIA'S REPRESENTATION IN THE EEAS'S AD STAFF}

\subsection{Trends between 2012 and 2019}

Table 1 demonstrates that Slovakia's representation within the EEAS's AD staff was identical, in absolute numbers, in 2012 and in 2019. However, as the EEAS itself expanded over this period, there were less Slovaks as a share of total AD staff in 2019 than in 2012. Slovakia's representation in the AD staff was strongest (in both absolute and relative terms) in the years 2017 and 2018, and was weakest in 2015. Overall, Slovakia's representation was relatively stable, even considering the drop in representation between 2014 and 2016. This means that there is no clear, observable trend in Slovakia's representation in the AD staff between 2012 and 2019. Table 1 also demonstrates that Slovakia was better represented at the EEAS headquarters than it was in EU delegations, except for in 2015.

Table no 1. Slovaks in EEAS AD staff, 2012-2019.

\begin{tabular}{|c|c|c|c|c|c|c|c|c|c|}
\hline & \begin{tabular}{|l|}
$\mathbf{Y}$ \\
ea \\
$\mathbf{r}$ \\
\end{tabular} & 2012 & 2013 & 2014 & 2015 & 2016 & 2017 & 2018 & 2019 \\
\hline $\begin{array}{l}\text { Slovaks in AD staff at } \\
\text { headquarters }\end{array}$ & & 5 & n. a. & 3 & 2 & 3 & 5 & 6 & 5 \\
\hline $\begin{array}{l}\% \text { of EEAS's AD staff at } \\
\text { headquarters }\end{array}$ & $\mathrm{EU}$ & 0.92 & n. a. & 0.53 & 0.36 & 0.54 & 0.93 & 1.09 & 0.92 \\
\hline $\begin{array}{l}\text { Slovaks in AD staff in } 1 \\
\text { delegations }\end{array}$ & $\overline{\mathrm{EU}}$ & 3 & n. a. & 2 & 2 & 2 & 4 & 3 & 3 \\
\hline $\begin{array}{l}\% \text { of EEAS's AD staff in } 1 \\
\text { delegations }\end{array}$ & & 0.88 & n. a. & 0.52 & 0.52 & 0.51 & 1.01 & 0.76 & 0.77 \\
\hline
\end{tabular}




\begin{tabular}{|l|l|l|l|l|l|l|l|l|}
\hline $\begin{array}{l}\text { Slovaks in EEAS's total AD } \\
\text { staff }\end{array}$ & 7 & 5 & 4 & 5 & 9 & 9 & 8 \\
\hline $\begin{array}{l}\% \text { of Slovaks in EEAS's total } \\
\text { AD staff }\end{array}$ & 0.90 & 0.75 & 0.53 & 0.43 & 0.53 & 0.96 & 0.95 & 0.86 \\
\hline
\end{tabular}

Source: Author's own elaboration based on O'Sullivan 2012; European External Action Service, 2015; European External Action Service, 2016; European External Action Service, 2017; European External Action Service, 2018; Ministry of Foreign and European Affairs of the Slovak Republic, 2020.

Table 2 lists the formal status of the Slovaks who worked in the EEAS's AD staff between 2012 and 2019. It shows that, throughout this period (with the exception of 2015 and 2016), most Slovaks were TAs and some were officials. In addition, it shows that Slovaks did not comprise more than $0.5 \%$ of all officials during this period - less than half of Slovakia's percentage share of the overall EU population (about 1.1\% during the observed period).

Table no 2. Slovaks in the EEAS's AD staff (officials and TAs), 2012-2019.

\begin{tabular}{|l|l|l|l|l|l|l|l|l|}
\hline \multicolumn{1}{|l|}{ Year } & 2012 & 2013 & 2014 & 2015 & 2016 & 2017 & 2018 & 2019 \\
\hline $\begin{array}{l}\text { Slovak officials in the EEAS's } \\
\text { AD staff }\end{array}$ & 3 & 3 & 2 & 2 & 3 & 3 & 3 & 2 \\
\hline $\begin{array}{l}\text { \% of total officials in the } \\
\text { EEAS's AD staff }\end{array}$ & 0.45 & 0.48 & 0.32 & 0.32 & 0.47 & 0.48 & 0.48 & 0.33 \\
\hline $\begin{array}{l}\text { Slovak TAs in the EEAS's AD } \\
\text { staff }\end{array}$ & 5 & 4 & 3 & 2 & 2 & 6 & 6 & 6 \\
\hline $\begin{array}{l}\text { \% of total TAs in the EEAS's } \\
\text { AD staff }\end{array}$ & 2.02 & 1.30 & 0.94 & 0.65 & 0.67 & 1.95 & 1.89 & 1.87 \\
\hline Slovaks in AD staff - total & $\mathbf{8}$ & $\mathbf{7}$ & $\mathbf{5}$ & $\mathbf{4}$ & $\mathbf{5}$ & $\mathbf{9}$ & $\mathbf{9}$ & $\mathbf{8}$ \\
\hline \% of total EEAS AD staff & $\mathbf{0 . 9 0}$ & $\mathbf{0 . 7 5}$ & $\mathbf{0 . 5 3}$ & $\mathbf{0 . 4 3}$ & $\mathbf{0 . 5 3}$ & $\mathbf{0 . 9 6}$ & $\mathbf{0 . 9 5}$ & $\mathbf{0 . 8 6}$ \\
\hline
\end{tabular}

Source: Author's own elaboration based on O'Sullivan, 2012; European External Action Service 2013; European External Action Service 2015; European External Action Service 2016; European External Action Service 2017; European External Action Service 2018; Ministry of Foreign and European Affairs of the Slovak Republic 2020. 
Slovak representation within the EEAS's AD management staff was relatively poor in this period as well. At no point between 2012 and 2019 did Slovaks' share of the overall number of this type of staff exceed $0.8 \%$, and between 2014 and 2016, they were not represented at all (Table 3).

Table no 3. Slovaks in the EEAS's AD management staff, 2012-2019.

\begin{tabular}{|c|c|c|c|c|c|c|c|c|}
\hline Year & 2012 & 2013 & 2014 & 2015 & 2016 & 2017 & 2018 & 2019 \\
\hline $\begin{array}{l}\text { Slovaks in the EEAS's } \\
\text { AD management staff }\end{array}$ & 2 & 1 & 0 & 0 & 0 & 2 & 2 & 2 \\
\hline $\begin{array}{l}\% \text { of total EEAS AD } \\
\text { management staff }\end{array}$ & \begin{tabular}{|l|}
0.79 \\
\end{tabular} & 0.38 & 0.00 & 0.00 & 0.00 & 0.74 & \begin{tabular}{|l|}
0.76 \\
\end{tabular} & n. a. \\
\hline
\end{tabular}

Source: Author's own elaboration based on European External Action Service 2019;

Ministry of Foreign and European Affairs of the Slovak Republic 2020.

Between 2013 and 2016, Slovakia was not represented at all among the heads of EU delegations - a specific subcategory of the EEAS's AD management staff (Table 4). Between 2016 and 2019, Slovaks occupied two such positions approximately a $1.4 \%$ share, and thus more adequate representation than the posts described above.

Table no 4. Slovak heads of EU delegations, 2012-2019.

\begin{tabular}{|l|l|l|l|l|l|l|l|l|l|}
\hline & Year & $\mathbf{2 0 1 2}$ & $\mathbf{2 0 1 3}$ & $\mathbf{2 0 1 4}$ & $\mathbf{2 0 1 5}$ & $\mathbf{2 0 1 6}$ & $\mathbf{2 0 1 7}$ & $\mathbf{2 0 1 8}$ & $\mathbf{2 0 1 9}$ \\
\hline $\begin{array}{l}\text { Heads of EU } \\
\text { Delegations from } \\
\text { Slovakia }\end{array}$ & 1 & 0 & 0 & 0 & 0 & 2 & 2 & 2 \\
\hline $\begin{array}{l}\text { \% of all Heads of } \\
\text { EU Delegations }\end{array}$ & 0.7 & 0.0 & 0.0 & 0.0 & 0.0 & 1.4 & 1.4 & 1.4 \\
\hline
\end{tabular}

Source: Author's own elaboration based on European External Action Service 2019; Ministry of Foreign and European Affairs 2020.

These tables show that none of the managerial positions held by Slovaks between 2017 and 2019 were at the EEAS's headquarters. This fact - together 
with the fact that there were no Slovaks in the whole of the EEAS's AD management staff between 2014 and 2016 - means that Slovakia was not represented at all at the EEAS's headquarters in Brussels between 2014 and 2019.

\subsection{The status quo in 2019}

A comparison of the real numbers with the HNQ for 2019 (Table 5) shows that Slovakia was slightly underrepresented within the EEAS's AD staff in 2019. It was also underrepresented in the category of AD staff officials, and overrepresented within AD staff TAs. In addition, Table 5 shows that Slovakia was slightly underrepresented in EU delegations, represented adequately at the EEAS's headquarters, and adequately represented within the heads of EU delegations and the EEAS's AD management staff. However, it was underrepresented within the AD management staff at the EEAS's headquarters.

Table no 5. Slovaks in the EEAS's AD staff in 2019: real numbers and HNQ.

\begin{tabular}{|c|c|c|c|c|c|c|c|}
\hline & $\begin{array}{l}\text { Slovaks in } \\
\text { AD staff } \\
\text { (in total) }\end{array}$ & $\begin{array}{ll}\text { Slovaks in } \\
\text { AD staff in } \\
\text { headquarters }\end{array}$ & $\begin{array}{l}\text { Slovaks in } \\
\text { AD staff in } \\
\text { delegations }\end{array}$ & $\mid \begin{array}{lr}\text { Slovaks } \\
\text { in } & \text { AD } \\
\text { staff } & - \\
\text { officials } & \end{array}$ & \begin{tabular}{|lr} 
Slovaks \\
in & $\mathrm{AD}$ \\
staff & - \\
TAs &
\end{tabular} & \begin{tabular}{|l} 
Slovaks in \\
AD \\
management \\
ttaff \\
(total) \\
\end{tabular} & $\begin{array}{l}\text { Slovaks as } \\
\text { heads of } \\
\text { EU } \\
\text { delegations }\end{array}$ \\
\hline 2019 & 8 & 5 & 3 & 2 & 6 & 2 & 2 \\
\hline $2019_{\mathrm{HNQ}}$ & 9.91 & 5.77 & 4.14 & 6.51 & 3.40 & 2.76 & 1.49 \\
\hline Result & -1 & 0 & -1 & -4 & +2 & 0 & 0 \\
\hline
\end{tabular}

Source: Author's own calculation based on Ministry of Foreign and European Affairs of the Slovak Republic 2020.

Note: The share of Slovakia on the whole EU population was $1.06 \%$ in 2019 according to Eurostat. This value was used to calculate HNQs for 2019 (2019 $\left.{ }_{\mathrm{HNQ}}\right)$. 


\section{SLOVAKIA'S REPRESENTATION WITHIN THE EEAS'S AST STAFF, CONTRACT AGENTS, AND SNEs}

\subsection{Trends between 2012 and 2019}

Table 6 demonstrates that Slovakia's representation within the EEAS's AST staff increased significantly between 2012 and 2019. Despite this net growth, however, it should be noted that Slovakia was better represented in this category of EEAS staff between 2013 and 2016 than in 2019. Thus, Slovak representation within the EEAS's AST staff has been declining since 2016, and has not been adequate - in the last three years of the observed period, the share of Slovaks within the AST staff was never above $0.5 \%$. Table 6 also shows that Slovak representation within the EEAS's contract agents grew between 2012 and 2019 , and that in this period its share in this category of the EEAS's staff more or less corresponded to its share of the EU's population and was therefore adequate. Regarding SNEs, Slovakia was consistently well-represented between 2014 and 2019 (data were not available for 2012 and 2013).

Table no 6. Slovaks within the EEAS's AST staff, contract agents, and SNEs, 2012-2019.

\begin{tabular}{|c|c|c|c|c|c|c|c|c|}
\hline Year & 2012 & 2013 & 2014 & 2015 & 2016 & 2017 & 2018 & 2019 \\
\hline Slovak AST staff & 2 & 4 & 4 & 5 & 4 & 3 & 3 & 3 \\
\hline $\begin{array}{l}\% \text { of the EEAS's } \\
\text { total AST staff }\end{array}$ & 0.31 & 0.61 & 0.60 & 0.77 & 0.61 & 0.48 & 0.48 & 0.49 \\
\hline $\begin{array}{l}\text { Slovak contract } \\
\text { agents }\end{array}$ & 3 & 3 & 4 & 4 & 4 & 5 & 5 & 5 \\
\hline $\begin{array}{l}\% \text { of the EEAS's } \\
\text { total } \\
\text { agents }\end{array}$ & 0.94 & 0.94 & 1.15 & 1.12 & 1.01 & 1.19 & 1.09 & 1.05 \\
\hline Slovak SNEs & n. a. & n. a. & 4 & 5 & 5 & 4 & 5 & 5 \\
\hline $\begin{array}{l}\% \text { of the EEAS's } \\
\text { total SNEs }\end{array}$ & n. a. & n. a. & 0.99 & 1.15 & 1.12 & 0.89 & 1.14 & 1.10 \\
\hline
\end{tabular}


Source: Author's own elaboration based on O'Sullivan, 2012; European External Action Service 2015; European External Action Service 2016; European External Action Service 2017; European External Action Service 2018; Ministry of Foreign and European Affairs of the Slovak Republic 2020.

\subsection{Status quo in 2019}

Table 7 compares the real numbers of Slovaks within the EEAS's AST staff, contract agents, and SNEs in 2019 to that year's HNQ. It shows that in 2019 Slovakia was underrepresented within the EEAS's AST staff and adequately represented within the EEAS's contract agents and SNEs.

Table no 7. Slovaks within AST staff, Contract Agents, and SNEs in 2019: real numbers and HNQ.

\begin{tabular}{|l|l|l|l|}
\hline & $\begin{array}{l}\text { Slovaks } \\
\text { within } \\
\text { AST staff }\end{array}$ & $\begin{array}{l}\text { Slovaks } \\
\text { within } \\
\text { Contract } \\
\text { Agents }\end{array}$ & $\begin{array}{l}\text { Slovaks } \\
\text { within } \\
\text { SNEs }\end{array}$ \\
\hline 2019 & 3 & 5 & 5 \\
\hline $2019_{\mathrm{HNQ}}$ & 6.48 & 5.06 & 4.8 \\
\hline Result & -3 & 0 & 0 \\
\hline
\end{tabular}

Source: Author's own elaboration based on O'Sullivan, 2012; European External Action Service 2015; European External Action Service 2016; European External Action Service 2017; European External Action Service 2018; Ministry of Foreign and European Affairs of the Slovak Republic 2020.

Note: The share of Slovakia on the whole EU population was $1.06 \%$ in 2019 according to Eurostat. This value was used to calculate HNQs for 2019 (2019 ${ }_{\text {HNQ) }}$. 


\section{POSSIBLE FACTORS INFLUENCING SLOVAKIA'S PRESENCE IN THE EEAS'S AD STAFF}

The interviews with EU diplomats, conducted by the author of this study in 2019, indicate, the EU member states' success in getting their nationals into the EEAS's staff and, consequently, their presence in the EEAS population, may be influenced by several factors.

One of these is a national ministry of foreign affairs' willingness to send its diplomats to the EEAS. Even though EU member states often have a sincere interest in having 'their people' in the EEAS, interviews with diplomats working in the EEAS indicated that, in practice, some ministries of foreign affairs avoid sending their diplomats to the EEAS because they prefer to keep their most experienced in their own national diplomatic services (Interview 1, 2, 3, 4).

Another influential factor is a national ministry of foreign affairs' career advancement system relative to that of the EEAS. Although ministries are obliged to guarantee their diplomats a post within their own national diplomatic service after they return from their temporary delegation within the EEAS, they are not obliged to guarantee assignment to a particular post (the same position they held before, say, or a position within the same department) or even to a post of a particular seniority. When - as in the case with the Ministry of Foreign Affairs for the Slovak Republic - a national ministry of foreign affairs does not stipulate such guarantees for diplomats serving in the EEAS, returning diplomats may be assigned to posts with different specialisations and/or a post of a lower seniority than they had held before their departure. Thus, diplomats have the (largely justified) impression that working with the EEAS might slow their career advancement in their own national foreign service and be discouraged from applying for posts within the EEAS (Interview 1, 2, 3, 4). Thus, situations like Slovakia's may result in a lower number of Slovak applicants for work at the EEAS and ultimately contribute to its poor representation within the EEAS's staff.

In a similar vein, the institutional culture of a national ministry of foreign affairs may influence that country's representation within the EEAS. For instance, our 
interviews indicate that EEAS diplomats consider that their national colleagues' perceptions of their work in (or applications to work in) the EEAS can damage their professional image (Interview 1, 3, 4) by, for example, generating perceptions that they are not loyal to their own national foreign service (Interview 2, 3). This sometimes discourages diplomats from applying to positions within the EEAS.

The ways in which applicants are selected and accepted to posts within the EEAS are out of individual states' control and can influence representation at large. These are defined by EEAS itself and may, in practice, favour or disadvantage applicants from a certain group of EU member states - for example, EEAS applicants' English language abilities are evaluated during the selection process, which might put older diplomats from the former Soviet bloc at a disadvantage (Interview 1, 2, 3). In a similar way, the selection processes' emphasis on the number of internships applicants have held disadvantages older diplomats from the former Soviet bloc because internships with foreign services were not very common in the old Soviet Union (Interview 1, 2, 3). Furthermore, the selection process for the EEAS's AD management staff takes into account the number of subordinates whom the particular applicant managed in their own national diplomatic service. This disadvantages diplomats from smaller EU member states, whose diplomatic services are smaller, and thus require them to manage fewer subordinates, and thus make their applications weaker than those of their counterparts from larger member states (Interview 1, 3).

\section{CONCLUSIONS}

Between 2012 and 2019, Slovakia's representation within the EEAS's staff was adequate only among contract agents and SNEs. Slovakia was not adequately represented among the EEAS's AST staff throughout this period. In addition, it was adequately represented within the EEAS's AD staff - which represents the top if its bureaucratic hierarchy - towards the end of the observed period. The 
overall trends in Slovakia's representation within the EEAS's staff are shown in Figures 1 and 2.

Figure no 1. Total number of Slovaks in the EEAS's statutory staff, per category, 2012-2019.

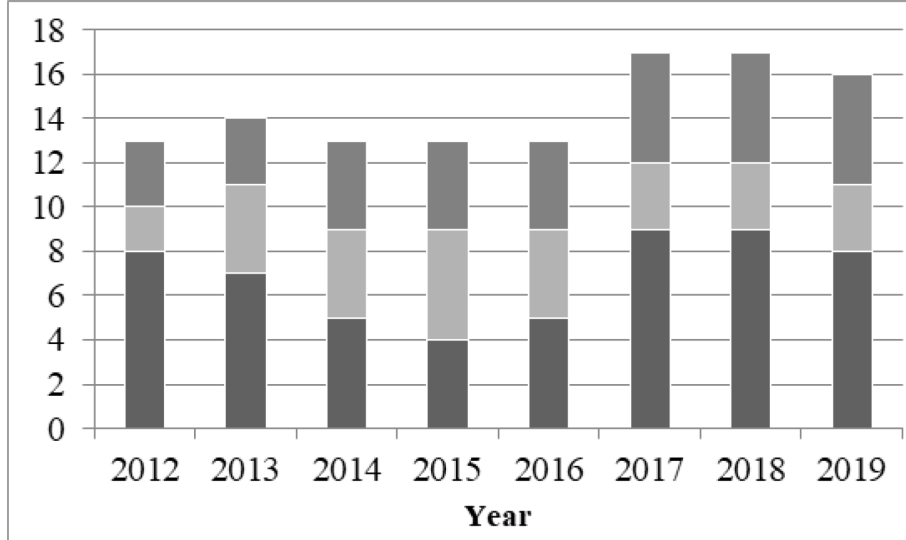

Contract

Agents

AST Staff

Source: Author's own elaboration based on O'Sullivan, 2012; European External Action Service 2015; European External Action Service 2016; European External Action Service 2017; European External Action Service 2018; Ministry of Foreign and European Affairs of the Slovak Republic 2020. 
Figure no 2. The EEAS's Slovak AD staff, AST staff, contract agents, and SNEs as a proportion of the EEAS's total staff, by category, compared with Slovakia's proportion of the total EU population, 2012-2019.

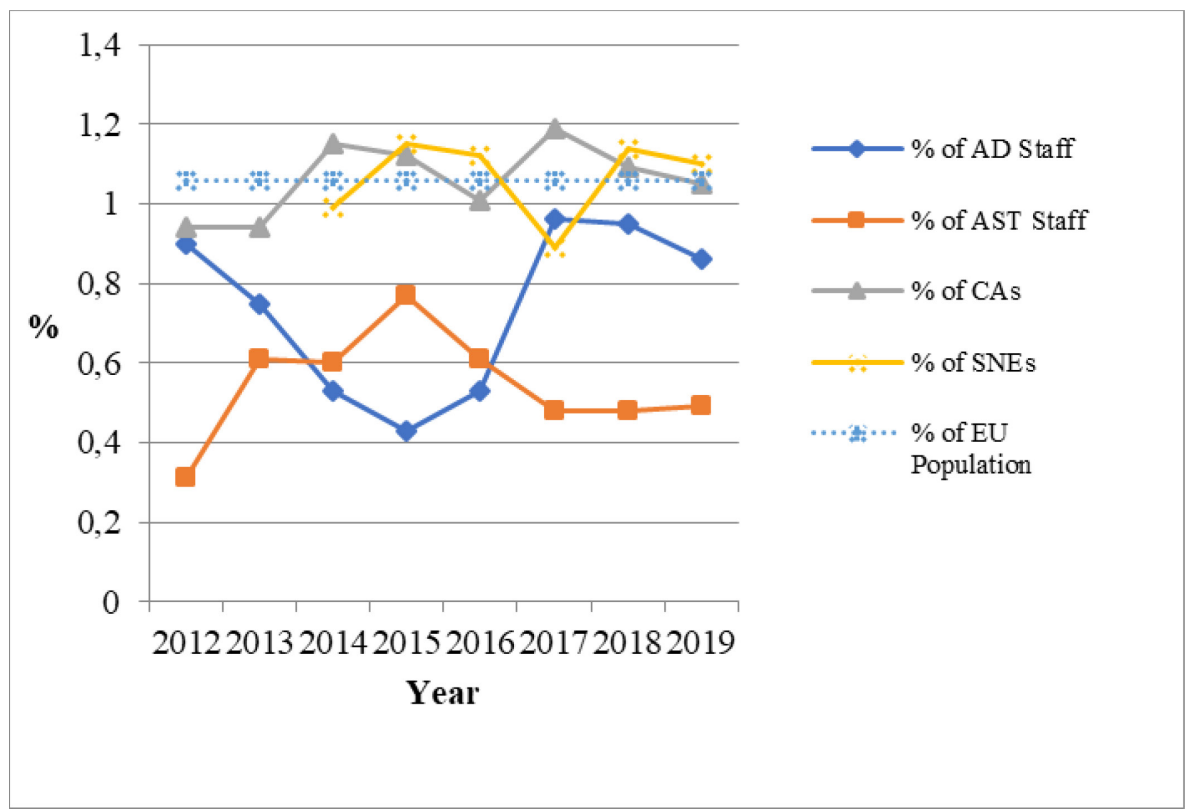

Source: Author's own elaboration based on O'Sullivan, 2012; European External Action Service 2015; European External Action Service 2016; European External Action Service 2017; European External Action Service 2018; Ministry of Foreign and European Affairs of the Slovak Republic 2020.

A close look at Slovakia's representation within the EEAS's AD staff reveals the following insights and reflections. First, most of the Slovaks in the EEAS's AD staff are TAs - only a few are officials. In other words, most Slovak representatives in the EEAS are diplomats who have been temporarily dispatched from Slovakia's national diplomatic service. This may benefit Slovakia's national diplomatic service by allowing TAs to acquire a wealth of European and national diplomatic experience. Second, Slovakia has consistently been better represented in the EEAS's AD staff at the EEAS headquarters than it 
has in EU delegations; however, the inverse is true regarding Slovak representation within the EEAS'S AD management staff. This distribution of representatives within the EEAS's AD management staff is far from ideal from Slovakia's point of view, not least because the AD staff in delegations has a considerably weaker influence on the EEAS's decision-making processes than the AD staff at EEAS headquarters.

Given these reflections, Slovakia's representation within the EEAS's staff between 2012 and 2019 cannot, on the whole, be assessed as adequate. This may be due to the Slovak Ministry of Foreign Affairs' overall attitude toward the work of its diplomats in the EEAS, its career advancement system, and its institutional culture, and to the conditions under which applicants are selected to posts within the EEAS.

On the basis of these findings, the following recommendations can be suggested:

1. The Slovak MFA should guarantee that diplomats returning from the EEAS to national diplomatic service will be given an appropriate post in terms of their seniority and professional specialization. This can help to ensure the diplomats, that their engagement in the EEAS will not slow down their diplomatic career progression or negatively affects their position in the national diplomatic service, so they will be better motivated to apply for posts in the EEAS.

2. The EEAS should adjust criteria for recruitment of AD staff in such a way that they will not disadvantage diplomats from Slovakia and will better acknowledge their specific knowledges and experiences (e. g. language skills, expertise in certain regions). This can help to improve the 'feeling of professional acceptance' by the EEAS among Slovak diplomats, and, thereby, to strengthen the 'sense of the ownership' of the EEAS by the Slovak MFA and the individual members of the Slovak diplomatic service.

Future research should evaluate which of the factors affect Slovakia's representation within the EEAS's staff the most. In addition, in future research it should be interesting to evaluate the Slovakia's success rate in getting its nationals into EEAS staff taking into account the 'weight' of the individual posts within the respective categories of EEAS staff. In particular, it should be interesting to take a look on the numbers of the higher and the lower managerial 
posts in the case of EEAS AD Management Staff, which may in reality be connected with a different rate of influence on the processes within EEAS. Likewise, for instance, in the case of Heads of EU Delegations and other AD Staff at the EU Delegations, it would be interesting to evaluate the representation of individual EU member states within these EEAS staff categories taking into account the diverse political importance of the receiving states in which these operate and from which follows the varying prestige, and therefore, the overall 'value' of these posts. ${ }^{2}$

\section{NOTES}

1. Usually for two four-year terms, but for no more than 10 years.

2. E.g. the post of the Head of EU Delegation in Washington, in Moscow or in Beijing in practice has a greater prestige than the post of Head of EU Delegation in some Pacific island state.

\section{ACKNOWLEDGEMENT}

The study is published within the framework of the research project VEGA No. $1 / 0437 / 20$ 'Potential and limits of the foreign policy of the Slovak Republic within the framework of the EU external relations'.

\section{REFERENCES}

- AFP. 2010. "Eastern EU states battle for posts in new foreign service." Times of Malta. September 2010. https://www.timesofmalta.com/articles/view/20100912/world/easterneu-states-battle-for-posts-in-newforeign-service.326615.

- Council of the European Union. 2010. Council Decision of 26 July 2010 establishing the organization and functioning of the European External 
Action Service (2010/427/EU). Official Journal of the European Union. L 201(03.08.201): 30-40.

- Dostál, Vít, and Anežka Fuchsová. 2019. „České“ zastoupení v Evropské službě pro vnějši činnost. Prague: Friedrich Naumann Foundation for Freedom, Central Europe and the Baltic States.

- Duke, Simon, and Sabina Kajnč Lange. 2013. Achieving Geographical and Gender Balance in the European External Action Service. Brussels: European Parliament, Directorate-General for External Policies, Policy Department.

- European External Action Service. 2013. EEAS Review. Brussels: European External Action Service.

- European External Action Service. 2015. EEAS Human Resources Report 2014, EEAS.MDR.C.1 - HR Policy and Coordination, Brussels: European External Action Service.

- European External Action Service. 2016. EEAS Human Resources Report 2015, EEAS.DG BA HR.1 - HR Policy and Coordination, Brussels: European External Action Service.

- European External Action Service. 2017. EEAS Human Resources Annual Report 2016, EEAS.DG BA.HR.1, HR Policy \& Coordination, Brussels: European External Action Service.

- European External Action Service. 2018. Human Resources Annual Report 2017, EEAS BA.HR.1 Human Resources Policy, Brussels: European External Action Service.

- European External Action Service. 2019. Human Resources Report 2018. Brussels: European External Action Service, Directorate General for Budget and Administration.

- Formuszewicz, Ryszarda, and Jakub Kumoch. 2010. The Practice of Appointing the Heads of EU Delegations in the Wake of Council Decision on the European External Action Service. Warsaw: The Polish Institute of International Affairs.

- Formuszewicz, Ryszarda, and Dorota Liszczyk. 2013. “The Staffing Policy of the European External Action Service - Stocktaking Ahead of the 2013 Review." The Polish Quarterly of International Affairs. 9, no. 1: 139-160. 
- Henökl, Thomas. 2014. “The European External Action Service: Torn Apart between Several Principals or Acting as a Smart 'Double-Agent'?". Journal of Contemporary European Research. 10. no. 4, 381-401.

- Ministry of Foreign Affairs, Republic of Slovenia. 2010. "Minister Žbogar takes part in FAC meeting." Press release. March 22, 2010. http://www.mzz.gov.si/en/newsroom/news/26706.

- Ministry of Foreign Affairs of the Czech Republic. 2010. "Minister Schwarzenberg in Brussels." Press release. July 27, 2010. https://www.mzv.cz/jnp/en/issues_and_press/archive/events_and_issu es/x2010/x2010_07_27_minister_schwarzenberg_in_brussels.html.

- Ministry of Foreign Affairs of the Republic of Latvia. 2010. “G. V. Kristovskis discusses with Ashton the co-operation concerning Latvian nationals abducted in Sudan". Press release November 12, 2010. http://www.mfa.gov.lv/en/news/latest-news/10791-g-v-kristovskisdiscusses-with-ashton-the-co-operation-concerning-latvian-nationalsabducted-in-sudan (Access: 18/08/2019).

- Ministry of Foreign and European Affairs of the Slovak Republic. 2020. Email communication on 6 April 2020.

- Novotná, Tereza. 2014. “Who's in charge? Member States, EU Institutions and the European External Action Service". ISPI Policy Brief. 228.

- O'Sullivan, David. 2012. Letter to Martin Schulz, President of the European Parliament, 18709/2012.

- Regulation No. 31 (EEC), 11 (EAEC), laying down the Staff Regulations of Officials and the Conditions of Employment of Other Servants of the European Economic Community and the European Atomic Energy Community. 2014. An official website of the European Union. Internet: https://op.europa.eu/en/publication-detail/-/publication/96f1d943-923a4848-8eb6-4c75dae8fca6/language-en (Access: 18/08/2019).

- Rettman, Andrew. 2010. "New EU states make bid for more diplomatic clout." EUobserver. March 2010. https://euobserver.com/institutional/2965. 
Interviews

- - Interview 1, Interview with the EU diplomat working at the EEAS Headquarters conducted by the author on 28 February 2019 in Brussels.

- - Interview 2, Interview with the EU diplomat working at the EEAS Headquarters conducted by the author on 5 March 2019 in Brussels.

- - Interview 3, Interview with the EU diplomat working at the EEAS Headquarters conducted by the author on 13 March 2019 in Brussels.

- - Interview 4, Interview with the EU diplomat working at the EEAS Headquarters conducted by the author on 14 March 2019 in Brussels. 